\title{
LIVE OR LET DIE? : FINE MARGINS BETWEEN LIFE AND DEATH IN A BRAIN-DEAD PREGNANCY
}

\begin{abstract}
Summary: In PP v Health Service Executive, the Irish High Court was recently asked to decide on the lawfulness of maintaining somatic treatment that was being provided to a brain-dead woman who was 15 weeks pregnant. In delivering judgment, Kearns P held that the treatment should not be maintained and that the artificial support being provided to the woman could lawfully be withdrawn. The legal basis for this ruling, however, is not free from criticism. The focus of this discussion is to consider how an English court would deal with a case similar to this should the need ever arise. There are crucial differences between English and Irish law which could impact upon the reasoning and, quite possibly, the outcome. Given that it is not beyond the realms of possibility that a similar case could occur in England at some point in the future, it is important that a number of legal questions are explored and their implications illuminated.
\end{abstract}

Keywords: Brain-stem death; woman; foetus; relatives; interests.

\section{INTRODUCTION}

It is difficult to conceive of a more tragic scenario than one in which a woman suffers a severe accident or illness during the course of pregnancy. The immediate concern should rightly be for her health and wellbeing, but the situation is of course exacerbated by the existence of a foetus. The hope should always be that the woman will recover from the trauma that she has endured and that her pregnancy will be unaffected, but, unfortunately, in a small number of cases there will be no such happy ending. The injury she suffers may be so catastrophic that her chance of making a meaningful recovery is incredibly remote, or, worse still, it may have rendered her brain-stem dead. While there will be undoubted sadness and concern for her, it is not just her position than needs to be examined in a legal sense. Concomitant with the woman's interests being one important consideration, there are also the interests of the foetus to contemplate.

As a result of advances in modern medicine, in exceptionally rare cases it has now become feasible to provide somatic support for a brain-dead pregnant woman in order to maintain the foetus, possibly up to a point of viability.1 Where a pregnant woman is in a serious condition, albeit with a chance of making some sort of recovery, medical support can be provided with a view to

1 See Racel A. Farragher and John G. Laffey, 'Maternal Brain Death and Somatic Support' (2005) 3 Neurocritical Care 99; Alan Lane et al., 'Maternal Brain Death: Medical, Ethical and Legal Issues' (2004) 30 Intensive Care Medicine 1484; Daniel Sperling, ‘Maternal Brain Death' (2004) 30 American Journal of Law and Medicine 453. 
sustaining both her and the foetus.2 Moreover, even where there is no chance of recovery for the woman, and where she has been pronounced brain-stem dead, it is still possible to provide somatic support to maintain the foetus.3 In this latter scenario, artificial support is provided to 'sustain' the woman in order to allow the foetus to continue to develop in utero, up until a point at which it may be possible for it to survive independently. It is this vexed situation which provides the main focal point of discussion for this article.

Where the woman has been pronounced brain-stem dead, she is, to adopt an unfortunate turn of phrase, viewed as a 'ventilated corpse' in the eyes of the law.4 She is sustained only for the benefit of the foetus, and her body is effectively being used as nothing more than an incubator. Using a woman's body in this way, as a mere means to an end, does not sit easily with some.5 Aside from these challenging ethical dilemmas though, there are equally difficult legal questions that need to be considered.

In $P P v$ Health Service Executive (hereafter ' $P P$ '), the Irish High Court was recently asked to decide on the lawfulness of maintaining somatic treatment that was being provided to a braindead woman who was 15 weeks pregnant. 6 In delivering judgment, Kearns P held that the treatment should not be maintained and that the artificial support being provided to the woman could lawfully be withdrawn. The legal basis for this ruling, however, is not free from criticism.7 It is not my intention to re-analyse the judgment of the Irish High Court in $P P$, for this has been performed admirably elsewhere. 8 Rather, the focus of this discussion is to consider how an English

2 JJ Finerty et al., 'Cerebral Arteriovenous Malformation in Pregnancy: Presentation and Neurologic, Obstetric, and Ethical Significance' (1999) 181 American Journal of Obstetrics and Gynaecology 296.

3 Majid Esmaeilzadeh et al., 'One Life Ends, Another Begins: Management of a Brain-Dead Pregnant Mother-A Systematic Review-‘ (2010) 74 BMJ Medicine DOI: 10.1186/1741-7015-8-74; IM Bernstein et al., 'Maternal Brain Death and Prolonged Fetal Survival' (1989) 74 Obstetrics \& Gynecology 437.

4 Per Lord Browne-Wilkinson in Airedale NHS Trust v Bland [1993] AC 789, p. 878.

5 See Abuhasna Said, et al. 'A Brain-Dead Pregnant Woman With Prolonged Somatic Support and Successful Neonatal Outcome: A Grand Rounds Case with a Detailed Review of Literature and Ethical Considerations' (2013) 3 International Journal if Illness and Critical Injury Science 220. See also the references to the ethical literature cited at $\mathrm{n}$ 1.

${ }_{6}$ PP v Health Service Executive [2014] IEHC 622. Kearns P delivered the only judgment of the Irish High Court. The judgment is unreported elsewhere. Thus, specific page references hereafter relate to a copy of the transcript downloaded from LexisNexis, accessed on 1/5/2016.

7 See Andrea Mulligan, 'Maternal Brain Death and Legal Protection of the Foetus in Ireland' (2015) 15 Medical Law International 182.

8 See Mulligan, ibid. See also Fiona De Londras, 'Constitutionalizing Fetal Rights: A Salutary Tale from Ireland' (2015) 22 Michigan Journal of Gender and Law 243. 
court would deal with a case similar to this should the need ever arise. There are crucial differences between English and Irish law which could impact upon the reasoning and, quite possibly, the outcome.9 Given that it is not beyond the realms of possibility that a similar case could occur in England at some point in the future, it is important that a number of legal questions are explored and their implications illuminated.

The narrative begins by setting the scene, where an overview of the judgment of the Irish High Court in $P P$ is provided. From this point onwards, the case is used merely as a hook to frame a forward-looking analysis, which seeks to explore the multifaceted legal issues that would need to be considered if the question of the lawfulness of maintaining somatic support for a brain-dead pregnant woman ever fell to be considered before a court in England. First, the question of determining a suitable approach under English law is explored. In this section I argue that there are a range of interests in play that need to be acknowledged, identified and then balanced against each other in order to determine the most appropriate course of action. Thereafter, I focus on the position of each of the parties in the scenario - the woman, the foetus, and the father and relatives and suggest that they all have interests that are worthy of at least some consideration by a judge in England if she is to construct a robust and defensible judgment.

\section{SETTING THE SCENE: AN IRISH PERSPECTIVE}

On the 26th December 2014, the Irish High Court handed down judgment in PP.10 Despite being described as 'not merely a rare case, but an absolutely extraordinary one', in a factual sense it is largely uncomplicated. 11 On the 29th November 2014, the patient, NP, suffered a fall while in hospital. This was as a result of a cyst which had been developing on her brain, which had been causing her to experience severe headaches and episodes of dizziness.12 The injuries she sustained from this fall eventually led to her being diagnosed as brain-stem dead. Once this diagnosis is confirmed, a patient is both medically and legally dead.13 Ordinarily in these circumstances it would

9 This is due to the fact that Article 40.3.3 of the Irish Constitution provides a constitutional protection for the foetus that does not exist under English Law.

$10 P P$, n 6.

11 Citing the medical evidence of Dr McKenna in PP, n 6 at 7.

$12 P P, \mathrm{n} 6$ at 4.

${ }_{13}$ See $R v$ Malcherek [1981] 1 WLR 690; Bland, $\mathrm{n} 4$. Brain-stem death is accepted by the majority of countries in the word as being the point of death. See WF Haupt and J Rudolph, 'European Brain Death Codes: A Comparsion of National Guidelines' (1999) 246 Journal of Neurology 432. 
be legitimate to discontinue any artificial life-sustaining treatment being provided to the patient, as its continuance would be futile.14 Nonetheless, an added layer of complexity was present in this case as NP was, in fact, 15 weeks pregnant.15 As the Irish Constitution provides specific protection for the foetus, the medical team in the case were reluctant to withdraw the somatic care that was being provided to sustain NP and her foetus for fear of the potential legal ramifications of doing So.16

The Plaintiff in the case was NP's father who, along with the father of the unborn child (MJ), believed that the prolonged somatic support measures were 'experimental in nature' and had 'no proper basis in medical science or ethical principle'.17 As such, he sought a declaration from the Irish High Court, by the exercise of its inherent jurisdiction, that the prolonged somatic support was unlawful and should be discontinued. The declaration was granted in his favour.18 A key influencing factor in this reasoning was that the Irish Constitution provides explicit protection for the unborn child. Article 40.3.3 of the Constitution states that 'the State acknowledges the right to life of the unborn and, with due regard to the equal right to life of the woman, guarantees in its laws to respect, and, as far as is practicable, by its laws to defend and vindicate that right'.19 The medical evidence in the case was unequivocal and indicated that the unborn child had 'no realistic prospect of emerging alive' 20 and had nothing but 'distress and death in prospect'.21 Accordingly, it was held by Kearns $\mathrm{P}$ that the somatic support being administered to the woman and unborn child was futile and could thus be legitimately withdrawn because it was in the best interests of the foetus to do so.22

While it is difficult to disagree with the outcome of the case, the reasoning is potentially problematic and actually raises more questions than it answers. If a similar case fell to be resolved

14 See Bland, n 4; see also $R$ (on the application of Burke) v General Medical Council [2005] EWCA Civ 1003; [2006] QB 273 .

$15 P P, \mathrm{n} 6$ at 1.

$16 P P, \mathrm{n} 6$ at 4.

${ }_{17} P P, \mathrm{n} 6$ at 2.

$18 P P, \mathrm{n} 6$ at 1.

19 Article 40.3.3 of the Irish Constitution; set out in $P P, \mathrm{n} 6$ at 9.

$20 P P, \mathrm{n} 6$ at 4.

$21 P P$, n 6 at 13.

$22 P P, \mathrm{n} 6$ at 13. 
before an English court, it may well be that the outcome would be the same, but I suspect that the reasoning may be slightly different. It is to this potential future scenario that the analysis now turns its attention.

\section{DETERMINING A SUITABLE APPROACH UNDER ENGLISH LAW}

The decision in $P P$ was based on the protection that is afforded to the foetus under the Irish Constitution. As this protection does not exist in England, a degree of caution is needed when making comparative observations, as the law is very different in the two countries.

The starting point in English law is that the foetus does not have any independent legal status prior to birth.23 The intention behind this rule is that it is designed to avoid any potential conflict between the foetus and the woman, while she is still alive. To hold that the foetus has interests could potentially put the mother's health in jeopardy, and perhaps even her life. The difficult question under English law would then be to what extent this position ought to change once the woman has been pronounced brain-stem dead. At that point, in principle, neither the dead woman nor the foetus have any legally relevant interests in English law; the foetus has no legal status before it is born, and the woman is dead.24 This, however, is a narrow perspective for the law to adopt and I would argue that the situation does change slightly upon the death of the woman in a somatic pregnancy. As such, the basic principle of English law that does not recognise foetal interests at all would need to be modified. Rather than neither party having any recognisable legal interests, I would suggest that they both in fact have interests, and that both sets of interests would need to be considered in any decision making process.

First, in regard to the dead woman, one possibility is that she has an interest in having her dignity respected. The problem with the concept of dignity is that it is notoriously difficult to define.25 However, if a right to dignity is conceived as a right not to be exposed to treatment that demeans or humiliates, then arguably the somatic support being provided could amount to a

${ }_{23}$ See CP (A Child) v Criminal Injuries Compensation Authority [2014] EWCA Civ 1554; [2015] QB 459; Re F (In Utero) [1988] Fam 122; Paton v British Pregnancy Advisory Service Trustees and Another [1978] 3 WLR 687.

24 In respect of the woman, it was held in $\operatorname{Re} A$ [1992] 3 Med LR 303 that a patient who is brain-stem dead is no longer a person, despite the fact that they are attached to a ventilator. In respect of the foetus, in English law it has been held that it cannot have a right of its own until it is born and has a separate existence from a woman. See cases cited at $\mathrm{n} 23$. 
violation of the woman's right to die with dignity.26 Similarly, if dignity is viewed as a right not to be treated as a mere object, this is a right that ought to apply upon the death of a person just as much as it ought to apply where that person is alive.27 Using the body of a woman purely as an incubator for the benefit of something else would certainly seem offensive to any notion of allowing a person to die with dignity.

Considering things from a different angle, if autonomy is viewed as a concomitant aspect of a broader definition of dignity, or indeed as a right in itself, it could be argued that a woman's right to have her autonomous wishes respected flows from life into death. The notion of autonomy ought to include a right to make certain forward-looking capacitous decisions, as they allow an individual to exercise choice in shaping their own destiny.28 Therefore, if a person has the prescience and foresight to make a particular decision in their life about what should happen once they die, the law should take account of this. It follows that any previous values a woman may have held, or any views she may have expressed before she died, ought to be at least considered by any decision maker. Other areas of English law have indeed recognised that certain interests and rights continue to exist after death. Parallels can be drawn with the law relating to organ donation in England, where a patient has the right to consent before their death to the removal and subsequent use of their organs after they have died.29 The laws relating to assisted reproduction also stipulate that a person has the right to agree to their gametes being stored and used after their death, which must be respected.30 Moreover, English law has recently made provision for a person's prior wishes to be taken into account in determining where they should be buried.31 Thus, it becomes evident that there are a number of situations in which the law not only recognises, but also respects, the interests and rights of a dead person.

26 For discussion of dignity in this context see O Schachter, 'Human Dignity as a Normative Concept' (1983) 77 American Journal of International Law 848.

27 For discussion see Neal, n 25 at 33.

28 This has been referred to as 'precedent autonomy'. See Ronald Dworkin, Life's Dominion (Harper Collins 1993) at $224-229$.

29 Human Tissue Act 2004, section 3 (6) (a). See further discussion below in the context of advance decisions.

${ }_{30}$ See, for example, $R$ (on the application of $M$ ) $v$ Human Fertilisation and Embryology Authority [2016] EWCA Civ 611; [2017] 1 FLR 452; Warren v Care Fertility (Northampton) LTD [2014] EWHC 602; [2015] Fam 1. See also the Human Fertilisation and Embryology Act 2008, s 39. Where a man has provided sperm and then subsequently dies, where that sperm is used to conceive a child, this provision allows for that man to be registered as the father of a child after he has died, provided he gave appropriate consent while alive.

31 See Anstey v Mundle [2016] EWHC 1073 (Ch); [2016] Inquest LR 47. 
In terms of the foetus, while ordinarily under English law it enjoys no legal recognition independent of the woman, that position is based on English law wanting to avoid any potential conflict between the two parties where the interests of the foetus could threaten the health or life of the mother. In other words, the law wishes to avoid having to balance out any potential conflict of interests where the woman remains alive. However, where a woman dies the position of the foetus comes more sharply into focus. To acknowledge that it has interests at this point would not cause any potential harm to a woman's health or life because she is now dead. Indeed, the only interests of a dead woman that are threatened by the presence of the foetus now are any interests in dignity and autonomy that are accepted to exist after death. I have suggested above that those interests do exist and should be recognised, but certainly an argument could be constructed that the rights and interests of a woman in her death ought to be subordinated to any interest that the foetus has in survival and the potential for life.32 Thus, the position of the foetus cannot be swept aside so easily on the basis of legal pragmatism and its potentially for life ought now to become a relevant interest that requires adequate consideration in any decision making process. 33

On this basis, the view held by Sheikh and Cusack seems sensible. They suggest that when dealing with a pregnancy, there are two patients involved, the woman and the foetus.34 However, whereas they argue that where the woman dies, the doctor's remaining duty is to the foetus, and that any treatment decision should thus be made in its best interests, I would argue slightly differently. 35 The foetus ought to be viewed as a patient with interests worthy of consideration, but, equally, even where the woman has been diagnosed as brain-stem dead, I would argue that she continues to be a patient in the sense that she still has certain interests in dignity and autonomy, which any decision maker ought to respect in the same way they would with any living patient. Thus, we are left with a situation in which we have two patients, both with recognised interests that ought to at least be considered.

Once it is accepted that both parties have interests, we then begin to see how best interests does have a role in somatic pregnancy case because once those interests have been acknowledged, the next logical step is for any decision-maker to consider how best to promote and, where

\footnotetext{
32 For an interesting discussion see Jeffrey A Parness, 'Crimes Against the Unborn: Protecting and Respecting the Potentiality of Human Life' (1985) 22 Harvard Journal on Legislation 97; Jeffrey A Parness and Susan K Pritchard, 'To Be or Not to Be: Protecting the Unborn's Potentiality of Life' (1982) 51 University of Cincinnati Law Review 257.

33 Ibid.

34 Asim A Sheikh and Denis A Cusack, 'Maternal Brain Death, Pregnancy and the Foetus: The Medico-Legal Implications for Ireland' (2004) 23 Medicine and the Law 237 at 246.

35 Ibid.
} 
necessary, protect those interests. To this end, both sets of interests need to be considered and weighed against each other in order to ascertain which ought to be given priority in the specific circumstances. It is after this careful and reasoned balancing of the respective interests that a judge in England would be able to justify deciding on a particular course of action. Thus, a type of best interests assessment is required, albeit one that does not conform with a typical best interests examination, which usually focuses on weighing up the advantages and disadvantages of different courses of action for just one living patient.36 In the absence of any constitutional protection for the foetus, the difficulty under English law would then reside in determining which set of competing interests ought to take precedence and why.

Kearns $\mathrm{P}$ in $P P$ prioritised the best interests of the foetus, which he characterised as a 'child' who was 'living'. He did so based on the constitutional protection that is provided to the foetus under Irish law.37 Absent that specific protection, the justification for choosing to assess and prioritise best interests from the viewpoint of the foetus instead of the woman can only be that the foetus has a potential to be born and to enjoy a life in the future, whereas the woman, who is dead, does not. The potential for a life thus trumps the cessation of a life.38 There may be some merit in that contention, especially where the foetus is at, or at least very close to, a point at which it can be delivered and born, with few, if any, medical complications. On the other hand, as it is only the woman who has ever enjoyed any kind of life and independent existence, and as she is the only party that has ever been capable of forming her own views, opinions, values and beliefs, another interpretation is that her interests ought to be the dominant consideration in any balancing exercise, because the position of someone who has actually lived a life ought to take precedence over something that merely has the potential for life. Thus, under English law, the position is much less clear as to how the respective interests of both parties should be balanced out against each other and which should be afforded the greater importance.

That neither a foetus nor a brain-dead woman is alive in a way that English law recognises poses a further procedural challenge. Due to the lack of any relevant supporting statutory provisions, a court in England would have to rely on the exercise of its inherent jurisdiction in order

\footnotetext{
36 Typical examples, amongst others, would be $W v M$ and Others at [2011] EWHC 2443 (Fam); [2012] 1 WLR 1653; $M v N$ [2015] EWCOP 76; [2016] COPLR 88.

$37 P P, \mathrm{n} 6$ at 11.

38 For discussion, see the literature cited at n 32 .
} 
to make a decision in a case similar to that of $P P .39$ This in itself would call for some consideration of the limits of a judge's power under the inherent jurisdiction and whether in fact it was seen as appropriate to extend its remit to accommodate a foetus and a dead person. In order to add credence to the argument that a type of best interests balancing exercise would the most effective way to justify any decision under English law, it is now necessary to look more closely at the relevant interests that ought to be recognised, and then to explore precisely what factors ought to be taken into account in a wider and holistic balancing of interests exercise that considers all parties in a brain-dead pregnancy.

\section{THE WOMAN'S PERSPECTIVE}

\section{A. Interests Worthy of Consideration?}

Given the existence of the foetus, it is perhaps understandable that some may be inclined to view the position of the brain-dead pregnant woman as an irrelevant consideration. Nonetheless, for me and perhaps others, something does not sit easily about disregarding her position entirely. A common argument against paying any legal attention to the brain-dead woman is that upon death she has no interests at all and, as such, any notion of her having 'best' interests is incongruous.40 However, in the dying embers of his judgment in PP, Kearns $\mathrm{P}$ seemed to acknowledge that the medical opinion in support of discontinuing the somatic support was based on an assessment of the best interests of both the foetus and the woman, and he thus recognised her best interests were still relevant in death.41 That was so, even though the kernel of his judgment was certainly not reasoned from that perspective.

As I have argued for earlier, Kearns P recognised that the woman still retained in death her right to respect for dignity and autonomy. $42 \mathrm{He}$ was 'unimpressed' by any suggestion that

\footnotetext{
39 The Mental Capacity Act 2005 would not apply to the woman, as she is dead. The Children Act 1989 would not apply to the foetus as it is not alive. The precise scope of the inherent jurisdiction is an incredibly complex issue and thorough discussion is beyond the scope of this article. However, for discussion, see the judgment of Munby $\mathrm{J}$ in $R e S A$ (Vulnerable Adult with Capacity: Marriage) [2005] EWHC 2942 (Fam); [2006] 1 FLR 867. This was later approved by the Court of Appeal in DL v A Local Authority \& Others [2012] EWCA Civ 253; [2013] Fam 1. See also Re F (Mental Patient: Sterilisation) [1990] 2 AC 1; and Norfolk County Council v PB [2014] EWCOP 14; [2015] COPLR 118. In terms of academic literature, see Margaret Hall, 'The Vulnerability Jurisdiction: Equity, Parens Patriae, and the Inherent Jurisdiction of the Court' (2016) 2 Canadian Journal of Comparative and Contemporary Law 185.
}

40 See $\operatorname{Re} A, \mathrm{n} 24$.

$41 P P$, n 6 at 11.

$42 P P, \mathrm{n} 6$ at 11. 
considerations pertaining to the dignity of the woman were not engaged once she had died, 43 and suggested that the rights of the unborn child must prevail, but only where those interests were not necessarily inimical to the rights of dignity and autonomy that belong to the woman. $44 \mathrm{He}$ concluded, on the facts of $P P$, that prioritising the rights of the foetus was not in any way harmful to the interests of dignity and autonomy enjoyed by the woman after her death, and in his view this justified considering best interests solely from its perspective.

To suggest that giving precedence to foetal interests was not in any way an affront to the dignity of the brain-dead woman seems curious. Through no fault of its own, the foetus was causing the woman to be maintained where, absence its presence, the artificial support that was sustaining her would have been withdrawn at a much earlier stage in proceedings, thereby allowing the woman to pass away peacefully and naturally. As it was, the woman's body was being used to provide a uterus which was, effectively, acting as 'an intensive care unit' to provide a supportive environment for the foetus.45 That is to say nothing of the fact that maintaining the woman in this way, purely for the benefit of the foetus, caused her to develop two serious infections in her skull, one of which led to a wound on the top of her head that had begun to grow organisms.46 Moreover, she suffered from fluctuating blood pressure, a urinary tract infection, and had started to show signs of suffering from pneumonia.47

All things considered, the evidence in $P P$ painted an extremely bleak picture of an undignified and horrific state of affairs that the woman would not have had to endure but for the presence of the foetus. This seems at odds with a finding that the existence of the foetus was not in any way harmful to her interests. On the contrary, the interests of the foetus, and what was medically necessary to maintain those interests, were, if not harmful to the woman's autonomy, at the very least, offensive to her dignity. Thus, Kearns $\mathrm{P}$ adopted a narrow perspective in this regard. As Mulligan has perceptively pointed out, it would have been interesting to see 'what the Court would have decided if the rights of the foetus were inimical to the privacy and dignity rights of NP' 48 , but exactly what it would have taken for the Irish High Court to reach that conclusion is

\footnotetext{
43 Ibid.

44 Ibid.

${ }_{45} P P, \mathrm{n} 6$ at 4.

46 Ibid.

47 Ibid.

48 Mulligan, $\mathrm{n} 7$ at 190.
} 
unclear. If, on the facts of $P P$, the interests of the foetus were not inimical to the woman's dignity in death, it is difficult to envisage any change of circumstances that may yield a different conclusion.

Once diagnosed as brain-stem dead, the medical prognosis and legal status of a pregnant woman will not change. The condition in which she is sustained may fluctuate from case to case and so it could be inferred from the judgment of Kearns $\mathrm{P}$ that the manner in which the woman was being maintained did not meet the minimum threshold required for it to amount to an assault on her dignity. However, that would seem to set the bar at an inordinately high level, as it would have to be some state of affairs for any woman to be sustained in a significantly worse position. Admittedly, the status of the foetus may change in that it could be at an earlier or later stage of development, but it is difficult to foresee how that variation would alter anything dramatically in regard to the woman's dignity in death being violated because it is the actual presence of the foetus and not its gestational status that is the main source of the problem. The reasoning of Kearns P could, therefore, be interpreted to mean that the only way in which the interests of a foetus could ever be inimical to a woman's rights of autonomy and dignity, is where she remains alive and considerations pertaining to her health and wellbeing are pitted directly against those of the foetus. This, however, directly contradicts the explicit recognition that a woman maintains the right to dignity and autonomy in death. Thus, the problem lies not in the fact that Kearns $\mathrm{P}$ failed to recognise the woman's relevant interests, but that he failed to adequately consider them in any type of appropriate balancing exercise. What possible options, then, would be open to a judge in England to allow her to approach a case concerning a brain-dead pregnant woman differently?

The inherent jurisdiction of the High Court in England extends to certain types of vulnerable adults who may fall outside the definition of adults who lack capacity for the purposes of the Mental Capacity Act 2005 (hereafter MCA 2005).49 According to Munby J, vulnerable adults who still enjoy the protection of the inherent jurisdiction include 'someone who, whether or not mentally incapacitated, and whether or not suffering from any mental illness, or mental disorder, is or may be unable to take care of him or herself, or unable to protect him or herself against significant harm or exploitation, or who is deaf, blind, or dumb, or who is substantially handicapped by illness, injury or congenital deformity'.50 Should an adult fall under any of these headings, any decision that has to

49 See cases cited at n 39. See also B Clough, "People Like That": Realising The Social Model In Mental Capacity Jurisprudence' (2015) 23 Medical Law Review 53.

50 Per Munby J in $R e S A, \mathrm{n} 39$ at [82]. See also $D L$ and $P B, \mathrm{n} 39$. 
be made on his or her behalf must also be made on the basis of best interests, albeit under its common law guise.

While it may call for an extension of the categories of individual listed above in order to accommodate a brain-dead pregnant woman within the definition of a vulnerable adult, it is possible that her position could fall within that meaning.51 Some of the debate may centre on whether in fact it is still possible to view her as an 'adult' after a diagnosis of brain-stem death. This would seem plausible though, as a brain-dead pregnant woman is still an adult, albeit one who is being maintained via somatic care and who has no chance of recovery. Thus, provided it is accepted that she has interests that are worthy of protection after death, a position argued for earlier in this piece, the inherent jurisdiction would seem to be the most appropriate source of legal power to protect those interests, despite her no longer being alive. To add further support to this, the essential question to consider is why the inherent jurisdiction continues to exist. It operates as a 'safety net' and is, in this sense, a useful tool in filling in the gaps left open by other laws.52 Thus, if we consider its main function as being to give power to judges to protect the rights and interests of those who cannot exercise them for themselves, and if it is accepted that a brain-dead pregnant woman does in fact maintain an interest in having her dignity and autonomy respected in death, then the argument that the inherent jurisdiction should remain sufficiently malleable so as to protect the woman by allowing those interests to at least be considered as part of a balancing exercise becomes more convincing.53 A brain-dead pregnant woman has a particular type of vulnerability where she is unable to protect herself against significant harm or exploitation, the latter of which she is capable of being subjected to as a result of maintaining her purely for the benefit of a developing foetus. As such, this is exactly the type of situation in which the inherent jurisdiction should be engaged. Certain jurisdictions have been more receptive than others to viewing the nature of the inherent jurisdiction's power as a continuum, something that can be exercised to make decisions on the basis of best interests in matters of both life and death.54 As of yet, English law

${ }_{51}$ See Jonathan Herring and Jesse Wall, 'Autonomy, Capacity and Vulnerable Adults: Filling the Gaps in the Mental Capacity Act' (2015) 35 Legal Studies 698; Michael C Dunn et al., 'To Empower or to Protect? Constructing the "Vulnerable Adult" in English Law and Public Policy' (2008) 28 Legal Studies 234.

52 Per Lord Donaldson MR in the Court of Appeal in Re F, n 39 at 13. See also Butler-Sloss P in Re A Local Authority (Inquiry: Restraint on Publication) [2003] EWHC 2746 (Fam); [2004] Fam 96 at [96].

53 See Margaret Hall, 'The Vulnerability Jurisdiction: Equity, Parens Patriae, and the Inherent Jurisdiction of the Court' (2016) 2 Canadian Journal of Comparative and Contemporary Law 185.

54 See the two New Zealand cases of Re JSB (A Child) [2010] 2 NZLR 236 (HC); and Takamore v Clarke [2012] NZSC 116 at [91]. 
has been unenthusiastic about this potential approach, despite the fact that judges have been seen to make certain decisions about patients after death.55 Thus, it may well be more sensible for English law to be explicit about the fact that the inherent jurisdiction enjoys a continuing power, which can be invoked where there is a legislative gap to make certain decisions about individuals once they have died.

\section{B. The European Convention on Human Rights}

A further consideration is how a judge in England may see fit to interpret the law in a manner that is consistent with certain Articles of the European Convention on Human Rights. Given that in PP Kearns P's explicit recognition of the woman's right to dignity and autonomy in her death became somewhat of a damp squib, it would be interesting to assess whether a judge in England would see fit to crystallise these rights into some form of concrete protection, and whether or not she would rely on certain convention rights to achieve this. 56

In regard to autonomy, Article 8 has clear relevance and will be discussed in more detail below in the context of advance decisions.57 In terms of dignity, there is no specific convention right that protects it. Nevertheless, if it is accepted that one view of dignity is concerned with preventing individuals being exposed to demeaning and humiliating treatment, and that persons should not be used as mere objects, Article 3 is closely aligned to these values and could be used to frame a right to dignity in the context of a somatic pregnancy.58 Thus, Article 3, as a natural corollary of protecting dignity, warrants further legal analysis. Article 3 provides that no one shall be subjected to torture or to inhuman or degrading treatment or punishment. It was held in Herczegfalvy $v$ Austria that 'as a general rule, a measure which is a therapeutic necessity cannot be regarded as inhuman or degrading. The Court must nevertheless satisfy itself that the medical necessity has been convincingly shown to exist'.59 This appears to leave open the possibility that once a treatment has exhausted any therapeutic necessity, to continue to subject a patient to that treatment regime could, in theory, amount to inhuman or degrading treatment. Indeed, it has been

55 See Re JS (Disposal of Body) [2016] EWHC 2859 (arrangements for dealing with body after death). See also Spencer v Anderson [2016] EWHC 851 (Fam) (paternity testing after death); Anstey, n 31 (succession and place of burial).

${ }_{56}$ See Neal, n 25.

57 See pp $17-22$.

58 See Schachter, $\mathrm{n} 26$.

59 Herczegfalvy v Austria (1992) 15 EHRR 437 at [82]. 
accepted that Article 3 specifically includes a right to die with dignity.60 One apparent obstacle, though, is found in the dictum of Butler-Sloss $\mathrm{P}$ in NHS Trust $A$ v M:61

'I am, moreover, satisfied that Article 3 requires the victim to be aware of the inhuman and degrading treatment which he or she is experiencing or at least to be in a state of physical or mental suffering. An insensate patient suffering from permanent vegetative state has no feelings and no comprehension of the treatment accorded to him or her.' 62

Arguably, this is quite a restrictive view of Article 3 and its potential applicability to patients who are forced to endure overly burdensome and futile treatment regimes. It is possible to argue that the emphasis should not be placed on what a person actually experiences from the treatment but, rather, on the substantive nature of the treatment itself and what they are actually being exposed to. The definition of inhuman and degrading treatment should, therefore, encompass both an objective and subjective element, with the 'baseline' objective standard being an integral factor in determining whether or not Article 3 should bite. An equally important question to consider is when the harm to the right is said to occur. In the case of a brain-dead pregnancy, some may claim that any harm caused to the woman's dignity only occurs after the point of brain-death and so Article 3 cannot be engaged.63 However, that is a narrow way to look at things. It is not the case that a woman is pronounced brain-stem dead and is then suddenly hooked up to an invasive lifesustaining treatment regime. She will actually be subjected to that treatment while she is still alive, albeit in a position where she is incapable of exercising any of her rights to prevent that treatment from being administered. The treatment then continues after the point at which she has become legally dead. Thus, if the right was capable of being engaged just before the point of death, but where a patient was in fact unable to enforce it by virtue of her condition, then that right should continue to exist once the patient has crossed the line into brain-stem death, where a court may then be actually in a position to enforce it on behalf of the patient by way of a declaration. In other words, the right should transcend protecting dignity at the end of a patient's life to protecting dignity in her actual death.64 When viewed in this way, Article 3 could be a useful mechanism by which to ensure that the interests of the woman are accounted for in a balancing exercise.

\footnotetext{
60 An NHS Trust v D [2000] 2 FLR 677; D v United Kingdom (1997) 24 EHRR 423; 2 BHRC 273.

61 NHS Trust A v M [2001] Fam 348.

62 Ibid at p. 363.

63 For discussion of the applicability of convention rights after death, see n 92.

64 For an interesting argument about the nature of rights after death, see Sheelagh McGuinness and Margaret Brazier, 'Respecting the Living Means Respecting the Dead too' (2008) 28 Oxford Journal of Legal Studies 297.
} 


\section{The Woman's Interests: Relevant Considerations}

At this point, it is perhaps worth restating the precise nature of my argument. It is not that a braindead pregnant woman's interests should be prioritised to the complete exclusion of the interests of the foetus, but that it would be inappropriate for a judge in England to preclude her position entirely from any balancing of interests exercise, as Kearns P did in PP. Indeed, under English law one may be entitled to raise the legitimate question as to why this is a concern at all, given that in England the foetus does not have any legal status prior to birth.65 As identified earlier, this is based on a pragmatic approach that is designed to avoid conflicts between the interests of the pregnant woman and the foetus. Where the woman is dead, however, the justification for adopting that approach is not as strong and the argument for a line of reasoning that balances out the potentiality of the life of the foetus against the woman's rights to autonomy and dignity in death becomes more credible. As such, the next important question is which considerations ought to be factored into the equation?

In respect of the medical considerations, it was famously stated in the English House of Lords' decision in Bland that where a patient is in persistent vegetative state (PVS), no balancing of the patient's best interests needs to take place because all the evidence points in one direction - in favour of withdrawing the treatment.66 That judgment was delivered when best interests was dominated by a medical understanding of the term, 67 but now there is at least some authority to suggest that this reasoning may not survive the introduction of the MCA 2005.68 As such, the medical evidence may well be futile in a case concerning a PVS patient, but that is just one consideration that needs to be factored into a much wider and holistic assessment of best interests under section 4 of the MCA 2005, and its newfound appetite for subjectivity.69

In terms of a brain-dead pregnant woman, the medical evidence will, similarly, point in one direction insofar as any prospects of recovery are concerned. Thus, it may be easier to argue that her medical interests should be subordinated to that of the foetus, especially where there is a realistic prospect of survival for the latter. However, that does not mean that the indignities

\footnotetext{
65 See cases cited at $\mathrm{n} 23$.

66 Per Lord Goff in Bland, n 4 at 869.

${ }_{67}$ See $\operatorname{Re} F, \mathrm{n} 39$.

${ }_{68}$ See Ahsan v University Hospitals Leicester NHS Trust [2006] EWHC 2624. For discussion see Rob Heywood, 'Moving on From Bland: The Evolution of the Law and Minimally Conscious Patients' (2014) 22 Medical Law Review 548.

${ }_{69}$ See Wye Valley NHS Trust v B [2015] EWCOP 60; [2015] COPLR 843; Mv N, n 36.
} 
associated with her treatment regime should be overlooked and completely disregarded. Her right to dignity in death is a relevant factor that should be considered by a judge, as I have argued for above. Equally, beyond that, recognition of the need for other important factors to not only be accounted for, but also given careful consideration, is imperative in contemplating the position of the woman. Before the inception of the MCA 2005, the piecemeal development of the common law recognised that best interests meant not only medical, but also social, psychological and emotional best interests.70 Presumably, then, if a judge in England decided it was in fact appropriate to at least consider the interests of the brain-dead pregnant woman, even though not directly applicable, she would be guided by the specific provisions of the MCA 2005 in developing the common law meaning of best interests. 71

It is an easy trap to fall into to think that every pregnant woman would want to be maintained after a diagnosis of brain-stem death in order to give her foetus the best shot at life. It may well be that many women would hold that view, but it should never be assumed. That is why it is important to include reference to the woman's position, as this gives due recognition to her as a once human being who had the opportunity to form and express opinions about what she would want to happen to her body in a given situation. Thus, a judge in England ought to consider, so far as is reasonably ascertainable, any evidence relating to the values and beliefs of a woman which may have impacted upon her potential decision.72 Similarly, a judge should consider any evidence relating to the past wishes of a pregnant woman as to what her views may well have been in regard to maintaining somatic care after a diagnosis of brain-stem death.73 This is in no way to suggest that evidence pertaining to the views, values and beliefs of the woman should be treated as determinative in deciding the outcome of a case, but in order to give due respect to her interests they should be considered.74

\footnotetext{
70 In Re A (Mental Patient: Sterilisation) [2000] 1 FLR 549 at 555 it was stated by Butler-Sloss P that best interests under the common law encompassed 'medical, emotional and all other welfare issues'.

71 For general discussion see Richard Huxtable, 'Autonomy, Best Interests and the Public Interest: Treatment, NonTreatment and the Values of Medical Law' (2014) 22 Medical Law Review 459.

72 The decision-maker is specifically instructed to consider these factors as part of the best interests assessment under the terms of the Mental Capacity Act 2005. Mental Capacity Act 2005, section 4 (6) (b).

73 Mental Capacity Act 2005, section 4 (6) (a).

74 Ford discussion of the precise weight that should be placed on patient's views see the comments made by Munby $\mathrm{J}$ in ITW $v$ Z and Others [2009] EWHC 2525 (Fam); [2011] 1 WLR 344 at [35]. See also Mary Donnelly, 'Best Interests, Patient Participation and the Mental Capacity Act 2005' (2009) 17 Medical Law Review 1.
} 


\section{The Woman's Perspective: An Advance Decision}

The concept of autonomy raises an interesting question in respect of advance decisions. The pertinent issue for a judge under English law would be the status of any such decision after a diagnosis of brain-stem death. There was no advance decision in PP. Nonetheless, Mulligan, speculating on what the Irish legal position would be in respect of an advance decision, suggests that where the woman is deceased 'the High Court would likely follow $P P$ in subordinating the interests of the deceased woman to those of the foetus'.75 Similarly, Peart el al., writing before the advent of the MCA 2005, suggest that the position in English law would also be similar in that 'if the woman is brain-stem dead, her advance directive will not be legally enforceable. Once brainstem death has been diagnosed patients cease to be persons in the eyes of the law and their right to determine what happens to their body is essentially non-existent'.76 While the introduction of statutory advance decisions under the MCA 2005 would have no direct bearing on a patient who has been diagnosed as brain-stem dead77, it is possible to question the continuing veracity of Peart et al. 's assertion in the light of modern attitudes and developments that have since taken shape in English law.78

In the same way that overlooking the woman's interests entirely feels uneasy, so too does the suggestion that any previously executed advance decision should be ignored at the point of brain-stem death. If a woman has the forethought to draft an advance decision to cater specifically for a situation in which she is pregnant and is left having to be medically maintained after a diagnosis of brain-stem death, and if she wishes to refuse treatment of this type, then, provided her advance decision was deemed both legally valid and applicable, it should be respected.

The more challenging question though is how, if indeed at all, English law could give legal recognition to any advance decision to refuse somatic care in a case concerning a brain-dead pregnant woman, absent any support from the MCA 2005. Prior to the inception of the MCA 2005, advance decisions were recognised under the common law but they were always vulnerable to

\footnotetext{
75 Mulligan, $\mathrm{n} 7$ at 193.

76 Nicola S Peart et al., 'Maintaining A Pregnancy Following Loss of Capacity' (2000) 8 Medical Law Review 275 at 283. See also Williams $v$ Williams [1882] LR $20 \mathrm{ChD} 659$, which established that a dead body is not property. Thus, in English law, there is no right to dictate the treatment of one's body after death.

77 The Mental Capacity Act 2005, section 24, introduced statutory advance decisions.

78 See Rob Heywood, 'Revisiting Advance Decision Making Under the Mental Capacity Act 2005: A Tale of Mixed Messages' (2015) 23 Medical Law Review 81; Sabine Michalowski, 'Advance Refusals of Life-Sustaining Medical Treatment: The Relativity of An Absolute Right' (2005) 68 Modern Law Review 958.
} 
attack. 79 First, there was unease amongst judges about the evidential uncertainty that surrounded them80, and, secondly, in order to balance out the problem of 'personhood', there were a number of ways in which it was acceptable to argue that an advance decision was no longer valid or applicable in the circumstances. 81 Thus, while the common law did recognise their use in theory as a means of future-oriented decision making to refuse medical treatment, seldom, if ever, did English judges enforce them.82 Upon a diagnosis of brain-stem death, the likelihood of any advance decision being deemed valid would have been remote; upon a diagnosis of brain-stem death accompanied by a potentially viable pregnancy, in all probability the chances would have gone from remote to nonexistent. That was under the common law as it was then, but would the situation change at all now?

The influence of the provisions of the MCA 2005 may now cause a judge in England to be more inclined to accept the validity of an advance decision. If a clearly drafted advance decision existed setting out a woman's wish to refuse somatic care in a brain-dead pregnancy, and if she had executed it in writing, signed it and had a witness countersign it, then, provided there was insufficient evidence to persuade a judge that it was no longer valid or applicable, there ought to be no reason in principle why that advance decision should not be respected. 83 The only difficulty would reside in whether a judge in England saw fit to ignore it completely by virtue of the fact that the pregnant woman was brain-dead.

It has been seen that Kearns $\mathrm{P}$ in $P P$ recognised that the woman retained the right to autonomy in her death. In view of that recognition, had an advance decision been present in $P P$, it would have been odd for Kearns P to completely disregard it.84 That is so irrespective of the fact that Irish law has not yet developed in the same way as English law in respect of advance

79 See Re AK (Adult Patient) (Medical Treatment: Consent) [2001] 1 FLR 129; Re C (Adult: Refusal of Medical Treatment) [1994] 1 WLR 290.

80 See Heywood, n 78.

${ }_{81}$ See Alasdair R. Maclean, 'Advance Directives and the Rocky Waters of Anticipatory Decision-Making' (2008) 16 Medical Law Review 1; Rebecca Dresser, 'Life, Death, And Incompetent Patients: Conceptual Infirmities and Hidden Values in the Law' (1986) 28 Arizona Law Review 373.

82 HE v A Hospital NHS Trust [2003] EWHC 1017 (Fam); [2003] 2 FLR 408.

83 The formalities required to execute a valid and applicable advance decision to refuse life saving treatment are contained in the Mental Capacity Act 2005, section 25 (2) - (6).

$84 P P, \mathrm{n} 6$ at 11. 
decisions. 85 In the light of this, it would have been interesting to see how the approach of the Irish High Court would have differed had anything rested on the existence of an advance decision.

Turning back to English law, is there anything else that may lend support to the argument that an advance decision should retain its legal force after death? Elsewhere it is not totally unheard of for the law to recognise certain types of autonomy after death. The Human Tissue Act 2004, for instance, recognises that where a patient has died, any valid consent that was in place immediately before death to consent to, or indeed refuse, organ donation, is a decision that ought to be respected in law as the patient's own.86 It follows that if a legally valid and applicable advance decision to refuse organ transplantation was in place prior to a patient dying, this would presumably need to be respected after that patient's death. 87 This is very much an issue-specific recognition though, and is provided for by a carefully defined bespoke set of legislative provisions. 88 Thus, to argue by analogy that a generalised acceptance in English law of advance decisions after death would be appropriate across the pisté may be susceptible to challenge.

Insofar as any human rights arguments are concerned, it is commonly accepted that Article 8 (1) engages a right to autonomy. 89 Nonetheless, it is a qualified right and so is sometimes easier to circumvent than some of the other absolute rights.90 Equally, the scope of Article 8 (1), as it relates to autonomy, is potentially much wider than, say, the ambit of Article 3. It is a right that has significant breadth, which could be engaged in a whole host of situations.91 As such, there is evidence at Strasbourg level that judges are reluctant to hold that it is capable of being engaged

85 Irish law does now make provisions for advance directives, but note that this Act has not been fully commenced. See Assisted Decision Making (Capacity) Act 2015.

86 Human Tissue Act 2004, section 3 (6) (a).

87 See McGuinness and Brazier, n 64.

88 Human Tissue Act 2004, section 3.

${ }_{89}$ See $R$ (on the application of Purdy) v DPP [2009] UKHL 45; [2010] 1 AC 345; Pretty v United Kingdom (2346/02) [2002] 2 FLR 45.

90 Article 8 (2) states that the Article 8 (1) right can be legitimately interfered with where it is necessary in a democratic society in the interests of national security, public safety or the economic well-being of the country, for the prevention of disorder or crime, for the protection of health or morals, or for the protection of the rights and freedoms of others. On this point, see Pretty, ibid. In a slightly different context, see Evans v United Kingdom (6339/05) [2007] 1 F.L.R. 1990. In terms of literature see Richard Buxton, 'Private Life and English Judges' (2009) 29 Oxford Journal of Legal Studies 413 .

91 See Buxton, ibid. 
after death92, for accepting that it could be may have far-reaching repercussions in a number of other fields, a point accurately captured by Mulligan who suggests that holding that the dead retain certain rights 'may have important implications in other contexts, such as defamation and privacy'.93 Nevertheless, in the context of best interests, the comments of Baker $\mathrm{J}$ in $W v M$ are of interest:

'due respect for the wishes and feelings of the patient, and for the wishes and feelings of other family members, has, of course, been a feature of the best interests assessment process since the decision in Bland. Thus a decision by the Court, having proper regard to the patient's personal autonomy and the expressed wishes and feelings of the patient and her family, that it would be in her best interests to withhold or withdraw treatment does not give rise to a breach of article 8.'94

The indication here is that there will be no breach of Article 8 where an appropriate best interests balancing exercise has been undertaken, having due regard to the range of relevant considerations pertaining to the wishes of the patient and her family members. Thus, a best interests assessment similar to that adopted by the Kearns $\mathrm{P}$ in $P P$, which overlooked entirely the position of the braindead pregnant woman, may not necessarily be interpreted as an appropriate best interests balancing exercise. In view of this, judges in England perhaps ought to be wary of discounting entirely any evidence pertaining to a brain-dead pregnant woman's past wishes in the form of not only an advance decision, but also beyond.

An advance decision does not have to be held to be legally valid in order for it to exert considerable influence on judicial reasoning. An emerging theme in English law has been for judges to consider any purported advance decision even if it is not technically legally valid. There have been cases in which an advance decision was not executed in accordance with the provisions of the MCA 2005 and, as such, was not legally binding, yet still judges have been prepared to treat it as persuasive evidence of what the patient would have wanted to happen.95 This was achieved by considering such evidence as a component part of the patient's past wishes, and also of their values

92 See Elberte v Latvia (2015) Application no. 61243/08; Petrova v Latvia (2014) Application no. 4605/05; The Estate of Kresten Filtenborg Mortensen v Denmark (2006) Application no. 1338/03; Jäggi v Switzerland (2006) Application no. $58757 / 00$.

93 Mulligan, $\mathrm{n} 7$ at 190.

94 Baker $\mathrm{J}$ in $W v M$ and Others, $\mathrm{n} 36$ at [95].

95 See X Primary Care Trust $v$ XB and YB [2012] EWHC 1390 (Fam); (2012) 127 BMLR 122; Re D (Withdrawal of Treatment) [2012] EWHC 885 (COP); [2012] All ER (D) 163. 
and beliefs, and choosing to prioritise that evidence in the best interests balancing exercise.96 Thus, where a patient has suffered an horrific brain injury with little if no prospect of recovery, if there was written evidence from her setting out her wishes to refuse treatment, then, regardless of whether it would amount to a 'legally valid' advance decision, judges have been seen to accept that withholding or withdrawing treatment would be in her best interests.97

As an extension of this, it has to be remembered that not every examination of a brain-dead pregnant woman's past wishes will lead to a conclusion that it is in her best interests for the somatic care to be withdrawn. On the contrary, the evidence may point to her wanting it to continue. The use of an advance decision therefore has limitations, for it could never be used to insist that the somatic care be provided.98 Any purported advance decision setting out such a request would be deemed invalid. Nevertheless, this does not mean that it should be completely overlooked. It should still be accounted for by reference to consideration of the woman's past views and wishes.99 If any advance decision was thus held to be invalid, whatever the reason for that finding, it is essential not to lose sight of the above, for in cases where the medical evidence is more finely balanced as to the survival of the foetus, what the brain-dead woman would have wanted to happen ought to be a more prominent consideration.

It may well be that, based on the particular facts of a brain-dead pregnancy case, a judge decided that this evidence was still not determinative and that emphasis should be placed elsewhere in the balancing exercise. There would be nothing untoward about that though, because the main issue of concern is not that the evidence is treated as being conclusive, but that it is actually considered as part of a judge's decision-making process. I now turn to consider the position of the foetus.

\section{THE PERSPECTIVE OF THE FOETUS}

\section{A. Determining the Correct Approach}

Whatever legal view is adopted in respect of the woman, the existence of the foetus would still remain a factor in determining the outcome of a somatic pregnancy case in English law. In $P P$,

\footnotetext{
96 See Heywood, n 78. The Mental Capacity Act 2005, section 4 (6) (a) states that any relevant written statement made by that patient when she had capacity has to be taken into account when considering her past and present wishes.

97 See cases cited at $\mathrm{n} 95$.

98 See Burke, n 14.

99 Mental Capacity Act, section 4 (6) (a).
} 
Kearns P reasoned best interests solely from the perspective of the foetus at the expense of all other parties to the debate.100 However, if an English court chose to follow this approach it would be exploring unchartered waters. This would be because, no matter how hard a judge may try, there is no disguising the fact that by answering the question of best interests only from the point of view of the foetus, she would, tacitly, be affording it a hitherto unrecognised legal status.

It is true that judges in England have sometimes made decisions, which, in terms of the net result, have implicitly recognised, and indeed protected, the interests of the foetus, and sometimes these judgments have been reasoned in a way that seem detrimental to the position of the woman.101 Rarely, if ever though, have these judgments been justified by explicitly prioritising the position of the foetus over that of the woman, notwithstanding that the outcome may have suggested otherwise. There have been a number of non-consensual caesarean cases in which such a procedure was ordered ostensibly to protect the woman and which culminated in the birth of a child.102 The rationale was often that the woman, as a result of a mental illness, was a danger to herself and was thus in no position to refuse such a procedure, or, alternatively, that her legal capacity to refuse such an operation had been destroyed and it was therefore necessary to authorise the treatment on the basis of her best interests.103 This is not the same as answering the question of best interests specifically and solely from the perspective of the foetus. Elsewhere, there are English criminal cases in which it has been acknowledged that the foetus has an interest which is worthy of a measure of protection in certain situations 104, and a degree of statutory protection also exists in different fields.105 Nevertheless, even in the light of those examples, English law has never been overtly considered exclusively from the position of the foetus.

\footnotetext{
$100 P P, \mathrm{n} 6$ at 11.
}

101 See St George's Healthcare NHS Trust v S [1999] Fam 26; Re MB (Caesarean Section) [1997] 2 FLR 426; Re S (Adult: Refusal of Treatment) [1993] Fam 123; Re T (Adult: Refusal of Treatment) [1993] Fam 95.

102 See Emma Walmsley, "Mama Mia! Serious Shortcomings With Another "(En) Forced" Caesarean Section Case Re AA [2012] EWHC 4378 (COP)' (2015) 23 Medical Law Review 135.

103 See Tameside and Glossop Acute Services NHS Trust v CH (A Patient) [1996] 1 FLR 762. See also the cases cited at n 101.

104 See Attorney-General's Reference (No. 3 of 1994) [1997] 3 WLR 421. See Emma Cave, The Mother of All Crimes (Ashgate 2004). Sara Fovargue and Jose Miola, 'Policing Pregnancy: Implications of the Attorney-General's Reference (No. 3 of 1994)' (1998) 6 Medical Law Review 265.

105 See the Abortion Act 1967 (as amended); the Infant Life (Preservation Act) 1929; Offences Against the Person Act 1861 , sections 58 and 59 . 
If a judge in England chose to follow the same line of reasoning as Kearns $\mathrm{P}$ in $P P$, it would go beyond the mere recognition of the foetus as having an interest. Holding that the best interests assessment needs to be considered from the perspective of the foetus alone would essentially afford to it a legal personality and would effectively transform any interest into a right; namely, the right to have the question of its best interests prioritised and answered exclusively by reference to it, and the upholding by a court of any ruling that flows directly from that assessment. Thus, it would perhaps be more appropriate to acknowledge that the foetus has interests which are worthy of consideration, but that those interests are capable of being balanced against other competing factors and, sometimes, overridden.

If the foetus formed part of the decision-making process, another challenge under English law is that subtle refinement of the High Court's inherent jurisdiction would be required to allow it to make a decision on behalf of something that has not yet acquired a legal status independent of a woman. While this power has clearly been extended to encompass decisions that need to be made on behalf of children, Re F (In Utero) seems to confirm that this power does not extend to decisions made about a foetus, at least where the mother is alive.106 This position undoubtedly reflects English law's pragmatic approach, highlighted earlier, that it is best to avoid any potential conflicts between a woman and her foetus. However, where the woman is dead, and the foetus does have the potential to survive, it could be argued that ignoring its presence completely is inappropriate. It might reasonably be suggested that the interests of something that has the potential for life ought to be at least balanced against any remaining interests of the dead woman, and that in some instances the foetal interests ought to be prioritised because at this stage there is no significant threat to the life or health of the woman. It would therefore seem sensible to suggest that the powers of the inherent jurisdiction could be invoked to crystallise any interests of the foetus that are considered to prevail, because the competing interests are much more delicately poised and require a more nuanced balancing exercise than when the woman is alive.107 Quite apart from these conceptual and procedural legal difficulties, there are other pressing legal questions that a judge in England would need to grapple with in terms of any attempt to determine best interests from the standpoint of the foetus.

106 See $\operatorname{Re} F, \mathrm{n} 23$.

107 For discussion and application of the inherent jurisdiction in respect of children see Re Y (A Child) (Withholding of Medical Treatment) [2016] EWHC 206 (Fam); Manchester University Hospitals NHS Foundation Trust v A [2015] EWHC 2828; Re OT [2009] EWHC 633, confirmed by the Court of Appeal in T v An NHS Trust [2009] EWCS Civ 409; Re L (A Child) (Medical Treatment: Benefit) [2004] EWHC 2713 (Fam); [2005] 1 FLR 491. In respect of the foetus, see $\operatorname{Re} F, \mathrm{n} 23$. 
There has been some debate of late in English law about the precise nature of the best interests test. In terms of mental capacity law, it was always viewed historically as an objective test.108 It is trite that the MCA 2005 now requires more subjective questions to be considered in the best interests assessment, yet, despite recent cases that suggest a subtle move towards complete subjectivity, best interests under section 4 of the MCA 2005 remains, in theory, an objective question.109 Where English courts have been asked to determine questions of welfare and best interests in regard to newborn babies, the problem of how to approach the best interests balancing exercise has been a little more complex.110 The distinction between objective and subjective approaches has become rather blurred, a problem which would be even more pronounced in relation to any best interests assessment of a foetus.111

Judges in England have attempted to develop a more comprehensive picture of the best interests balancing exercise that needs to take place where a child is concerned, but difficulties have become apparent due to conflicting statements as to precisely how it should be undertaken. In $A n$ NHS Trust $v$ MB, Holman $\mathrm{J}$ endorsed an objective approach. 112 Nevertheless, he acknowledged that the best interests test had to be interpreted in the widest possible sense, including 'every kind of consideration capable of impacting on the decision. These include, non-exhaustively, medical, emotional, sensory (pleasure, pain and suffering) and instinctive (the human instinct to survive) considerations'.113 Other cases, however, have been seen to contradict this. In Re J, Lord Donaldson MR suggested that the balancing exercise should: 'avoid looking at the problem from the point of view of the decider, but instead...look at it from the assumed point of view of the patient'.114 The introduction of subjectivity here may be appropriate in some cases, but it may serve to further muddy the waters in respect of a foetus.

108 See Re F, n 39.

109 See $M v N$, n 36; and Wye Valley, n 69.

110 See Mary Donnelly and Ursula Kilkelly, 'Child-Friendly Healthcare: Delivering on the Right to be Heard' (2011) 19 Medical Law Review 27; Margaret Brazier, 'An Intractable Dispute: When Parents and Professionals Disagree' (2005) 13 Medical Law Review 412.

111 The Children Act 1989, section 1 (3) stipulates that certain subjective considerations need to be taken into account when determining what is in the welfare of a child. See also Re OT, n 107; Portsmouth NHS Trust v Wyatt [2005] EWCA Civ 1181; [2005] 1 WLR 3995. See Rob Heywood, 'Parents and Medical Professionals: Conflict, Cooperation, and Best Interests' (2012) 20 Medical Law Review 29-44.

112 An NHS Trust v MB and Others [2006] EWHC 507 (Fam); [2006] 2 FLR 319 at [16].

113 Ibid.

114 Re J (A Minor) (Wardship: Medical Treatment) [1991] Fam. 33, p. 46. 
Looking at the question of best interests from the 'assumed view' of the patient is almost identical to the substituted judgement approach sometimes advocated in mental capacity law.115 This approach has not been wholly endorsed as of yet in England, but there is now a much greater emphasis on subjectivity in the best interests assessment.116 Attempting to place oneself in the shoes of a patient with a view to reaching a decision that she purportedly would have made is sometimes said to be an autonomy-enhancing approach to assessing best interests, but that is not always the case.117 While in some situations it may operate to this effect, in others it may not, for it has to be remembered that it is not the patient herself making the decision, it is a judge making the decision that she thinks the patient would make if capable of doing so. The number of different permutations that may influence the way in which an individual patient thinks about a particular decision, and subsequent range of interpretations that a judge may attach to these, cause this approach to become most unpredictable. Likewise, it creates a sense of confusion when a judge claims to have reached a decision that a patient would have made if she had had capacity, when in fact that patient may never have been in a position to exercise that capacity at all.118 This particular difficulty is especially relevant when any attempt is made to consider the assumed view of a foetus, which has never legally existed at all.

Nevertheless, in PP Kearns P favoured the approach advocated by Lord Donaldson MR in Re $J$, and the assumed view of the foetus thus took centre-stage in answering the best interests question. This was despite the fact that $R e J$ was heard in the English Court of Appeal back in 1990, and in a different context. 119 Should a similar case ever reach a court in England, this would not be the correct approach, because best interests still remains an objective test. Realistically, it is never possible for a judge to convincingly argue that she is capable of projecting herself into the shoes of something that has never existed in order to determine what it may or may not have wanted to happen in a given situation. The foetus has never enjoyed any life independent of a woman, so it will never have had the opportunity to form its own opinions, values and beliefs. It is also entirely

115 See the American case of Strunk v Strunk (1969) 445 S.W.2d 145.

116 See $M v N, \mathrm{n} 36$; and Wye Valley, n 69.

117 For discussion see Rob Heywood and Alexandra Mullock, 'The Value of Life in English Law: Revered But Not Sacred?' (2016) Legal Studies: DOI: 10.1111/lest.12131, p. 13.

118 See Louise Harmon, 'Falling Off the Vine: Legal Fictions and the Doctrine of Substituted Judgment' (1990) 100 The Yale Law Journal 1.

$119 P P, \mathrm{n} 6$ at 12. 
incapable of expressing any wishes, either past or present, as to what it would want to happen. As such, a judge has no frame of reference by which to guide her decision and certainly no way of substantiating it. The apparent emphasis on subjectivity, therefore, becomes illusionary and in a case concerning a somatic brain-dead pregnancy, a judge in England would need to be explicit about the need to carefully consider the medical evidence pertaining to the foetus from an objective angle. This is not without its own difficulties though, given the refined definition of futility that has recently taken shape in English law.

\section{B. The Medical Evidence: Assessing the Notion of Futility}

Despite the subtle movement away from medically-oriented best interests, it is an inescapable fact that in cases concerning the lawfulness of maintaining a brain-dead pregnancy, the medical evidence will have a huge part to play in determining the outcome. In the light of a diagnosis of brain-stem death, what would otherwise be important questions pertaining to the medical outlook of the woman fall away. Thus, the medical evidence only has a pivotal role in respect of the foetus. In $P P$, Kearns $\mathrm{P}$ analysed the medical evidence carefully and reached the conclusion that any attempt to sustain the foetus was futile and this was offered as the justification for withdrawing the somatic support.120 Current medical literature suggests that this may not always be the case though. 121 In a similar fashion to the Irish High Court, at a 15-week period of gestation it would be highly unlikely that a judge in England would be persuaded that the foetus stood any chance of survival.122 Yet, if the same line of reasoning were to be adopted as in $P P$, fast forward that gestation period by seven weeks and the complexion of the medical evidence in respect of the chances of foetal survival in a brain-dead pregnancy may change considerably, and so too the possibility of a different outcome.123 With this in mind, a number of observations can be made about how best to assess the medical evidence in a somatic pregnancy case.

From the point of view of the foetus, the concept of futility runs to the heart of the best interests assessment in cases such as $P P$. It is, however, a notoriously difficult concept to define.124

$120 P P, \mathrm{n} 6$ at 13.

121 See references to the medical literature, n $1-3$, and 5.

122 The Infant Life (Preservation) Act 1929, section 1 (2) states that a child is capable of being born alive at 28 weeks, but it was held in $C v S$ [1988] QB 135, p. 147, that a foetus is not capable of being born alive at 18 weeks.

123 See medical evidence cited at n $1-3$, and 5.

124 See RK Mohindra, 'Medical Futility: A Conceptual Model' (2007) 33 Journal of Medical Ethics 71; Nancy S Jecker and Robert A Pearlman, 'Medical Futility: Who Decides?' (1992) 152 Archives of Internal Medicine 1140; Ronald 
In Aintree in the Supreme Court, Lady Hale advocated an approach to the question of futility in English law that endorsed a subjective assessment, addressing the issue from the perspective of the patient. Thus, a treatment is not futile where it 'may bring some benefit to the patient even though it has no effect upon the underlying disease or disability'.125 This was at odds with the approach advocated by Sir Alan Ward in Aintree in the Court of Appeal, in which he endorsed a more medicalised and objective interpretation of futility, focusing on the treatment needing to have 'a real prospect of curing or at least palliating the life-threatening disease or illness from which the patient is suffering' in order not to be classified as futile.126

The problems identified above with regard to the injection of subjectivity in the broader best interests assessment of the foetus are accentuated when the specific question of futility is at stake. In order to retain any meaningful substance, the subjective branch of futility can only be considered by reference to the past and present views, wishes and beliefs of the patient as an individual. However, there is no way of ascertaining what a foetus may feel and think in respect of a proposed course of treatment. It could be argued that this foetus would regard any shot at life, no matter how slight and burdensome, as a risk worth taking. On the other hand, it could equally be argued that this foetus may not want to risk any shot at life which would cause it the slightest amount of pain and discomfort. There is simply no way of knowing which view ought to prevail and so any suggestion that futility can be analysed through the eyes of the foetus is misleading, for any purported subjectivity would become a mere disguise for a judge interposing her own objective view as to what she thought the foetus would consider a worthwhile treatment.

There is a further difficulty with the assessment of futility in this context. Kearns P stressed in $P P$ that he was only concerned with the question of whether, in fact, the unborn child could survive at all. Presumably then if the foetus had any chance of survival, no matter how slight, the overall conclusion to the case would have been different. Kearns P omitted from his reasoning any consideration of what the situation would have been had the child been capable of being born alive but thereafter been afflicted by some type of disability.127 This seems to be an incredibly narrow

Cranford and Lawrence Gostin, 'Futility: A Concept in Search of a Definition' (1992) 20 Law, Medicine and Healthcare 307.

125 Per Lady Hale in Aintree University Hospitals NHS Foundation Trust v James [2013] UKSC 67; [2014] AC 591 at [43].

126 Per Sir Alan Ward in Aintree University Hospitals NHS Foundation Trust v James [2013] EWCA Civ 65; [2013] 4 All ER 67 at [37].

127 PP, n 6 at 9. For discussion of the treatment of neonates, see Roland Hentschel, et al., 'Restriction of Ongoing Intensive Care in Neonates: A Prospective Study' (2006) 118 Pediatrics 563; Hazel E McHaffie, et al., 'Withholding / 
line of reasoning. The crucial issue should not just be about whether or not the foetus could indeed 'survive', but also about whether or not it could enjoy any meaningful and enjoyable existence after it has been born. It would seem a little incongruous to suggest that where there is a chance of foetal survival the woman should be sustained, notwithstanding the fact that any sustaining treatment may be unduly burdensome to the foetus in utero, and then, once born, its existence afflicted by severe medical problems which may make its life equally, if not more, painful to a point which borders on being inhuman.

The concept of intolerability is sometimes used as a gloss here on the best interests assessment, but the subjective connotations associated with that term are not particularly helpful.128 At best it can perhaps be used as a guide to assess the full spectrum of treatment regimes that will need to be administrated not only to sustain the foetus in utero, but also to ensure that it survives once born. Thus, if the medical evidence indicated that there was no chance of survival at all, or of only possible survival in the face of severe complications, illness and/or disability, it ought to be possible in this context to suggest that any somatic support is futile and so should be discontinued. Essential to answering this question would be the need for careful analysis of the potential medical treatments in terms of their respective burden to benefit ratios so as to ensure that any foetus, and any subsequent child that may be born alive, would not be exposed to treatment regimes which may cause considerable pain and distress without any future hope of improvement.

\section{VI. 'OTHER' INTERESTS: THE FATHER \& THE RELATIVES}

Beyond the interests of the woman and the foetus, there are also other 'interested' parties to consider. An interesting component to a brain-dead pregnancy case is the role and influence of the views of the father and the other relatives. This facet represents a key difference between English and Irish law. Irish law makes no provision for the inclusion of the views of family members in the best interests balancing exercise; the assessment is based purely on the clinical evidence.129 In English law, both the Children Act 1989 and the MCA 2005 contain statutory measures which stipulate that the views of parents, relatives, partners and other carers have to be considered.130

Withdrawing Treatment From Neonates: Legislation and Official Guidelines Across Europe' (1999) 25 Journal of Medical Ethics 440; Ellenchild Pinch, et al., 'Ethics in the Neonatal Intensive Care Unit: Parental Perceptions at Four Years Postdischarge' (1996) 19 Advances in Nursing Science 72.

128 See Portsmouth NHS Trust v Wyatt, n 111 at [91].

129 See Mulligan, n 7 at 192.

130 Mental Capacity Act 2005, section 4 (7) (b); Children Act 1989, section 1 (2A); section 1 (3) (a). 
Equally, the common law has long since recognised that these views also have to be taken into account when determining the question of best interests. 131

It is both sensible and correct that these views are heard, but in a case concerning the provision of somatic care to a brain-dead pregnant woman, accommodating these views becomes slightly more complicated than at first it may seem. While it may be possible to say that the father of the unborn child and the other relatives have an interest in a case such as this, the actual question of best interests can only be determined by reference to the individual patient about whom the decision actually has to be made. Thus, their views are only ever considered in the context of deciding what is in someone else's best interests. This is why it becomes important for a decision to be made about who the patient actually is. If the woman is said to be the only patient, the father and relatives may offer one perspective on what they feel is the best option. If, on the other hand, the foetus is identified as the only patient, they may provide an alternative view. Reflecting on my earlier argument that both parties should be treated as relevant patients, it may be most appropriate for a judge to invite the father and relatives to present their views in respect of what they feel would be the best course of action for both the woman and foetus.132 This would have the benefit of not creating a perception that evidence needs to be offered on behalf of one party to the total exclusion of the other. A judge could then factor these views into her decision-making process when seeking to balance out the interests of both the foetus and the woman to in order to determine which should be given priority.

A cogent argument could be made out that, in the absence of any other 'living' entity, the views of the father of the unborn child and any other relatives ought to carry considerable weight in this predicament. This is because, more often than not, they are the individuals who will be left having to look after any resultant child that is born. Thus, where the medical evidence is more finely balanced, a strong case could be made for these views attracting greater importance. This is where the narrow reasoning of Kearns $\mathrm{P}$ in $P P$ becomes apparent. The evidence in the case admittedly all pointed in one direction, yet, regardless, focusing exclusively on the mere chance of survival for the foetus overlooked an important question that those tasked with caring for any subsequent child may have had a strong view on. In addition to relatives having a view on whether somatic treatment should be continued at all so as to render survival possible, they may also have an opinion on the medical prognosis for the child once it has been born. Pertinent to their thought

131 See Bland, n 4. See also Holman J in NHS Trust v MB, n 112 at [16] [x].

132 This approach would be difficult to reconcile with other best interests decisions regarding newborn babies. See, for example, Portsmouth v Wyatt, n 111. 
processes may be whether or not any child, once born, will be capable of enjoying a 'normal' life unaffected by medical ailments, or whether there is the potential for it to suffer from a severe or life-changing disability. Depending on the answer to that question, the views of the relatives may change in regard to what they think would be the best course of action and, given the significant impact that any outcome in a case would have on their current and future lives, it could be argued that a judge should scrutinise these views very carefully in any decision-making process.

To reiterate, the views of the father and relatives should not be treated as conclusive by a judge in reaching her decision, for in some instances those views may be tainted by an improper motive and may not, in fact, have the best interests of the patient in mind. Their views, however, should be considered.133 Precisely what weight to attach to those views will vary in different situations. By way of illustration, had the wishes of the woman's family and the father of her unborn child indicated a preference for the treatment to continue, then, based on the medical evidence in $P P$, it would have been inappropriate to prioritise their wishes because of the futile nature of the somatic support.134 If the situation had been slightly different though, and if the medical evidence was more equivocal in respect of not only the chances of survival, but also as to the prognosis after birth, then in this scenario it may well be that the views of the father and relatives should come more sharply into focus. They may offer a view that they would not want to run that risk of giving the foetus any shot at life for fear of the negative impact it may have in its life, and also theirs, once it is born. They may feel, for example, that it would be unfair on the child itself to run the risk of it being born and to suffer extensively from medical complications or a severe disability. Similarly, they may also feel that they themselves will be unable to care, and provide adequate support, for any resultant child in the future.

However, if the medical evidence was equivocal in exactly the same way, and there was some evidence that the brain-dead pregnant woman would have wanted the somatic support to continue, and that this view was countenanced by the family who were accepting of any associated risks, then once again it is hoped that a judge would remain cognisant of such views and perhaps be more inclined to reach a conclusion that the somatic support should be maintained in order to give the foetus a chance at life. Each case will thus need to turn on its own merits, but it is crucial that the views and perspectives of all the interested parties are considered carefully in determining an appropriate outcome.

133 See $I T W v Z$ and Others, $\mathrm{n} 74$.

$134 P P, \mathrm{n} 6$ at 13. 


\section{CONCLUSIONS}

In regard to the legality of maintaining somatic support for a brain-dead pregnant woman, the decision of the Irish High Court in $P P$ is dangerous, not so much in terms of its outcome, but more in terms of its problematic reasoning in the context of England and Wales.

As such, I have suggested that if a case similar to the of $P P$ were ever to be heard before an English court, careful thought would need to be given as to how best to approach it. Unless it was in the very late stages of pregnancy, it would be highly unlikely that an English judge would adopt the same line of reasoning as Kearns P by looking at best interests exclusively from the standpoint of the foetus. In view of this, some consideration would need to be given to precisely how English law would accommodate the position of the brain-dead woman. I have argued that recognition of her retaining certain interests in death ought to allow a judge some scope to consider how best to protect those interests by balancing them out against the respective interests of the foetus in order to determine which should be given priority. I have also highlighted that it would not be open to a court in England to disregard the views of the child's father and relatives in the way that occurred in $P P$. Their views, while not determinative, ought to be considered by a judge in her decisionmaking process.

In sum, it would be more appropriate for a court in England and Wales to countenance a more holistic and rounded best interests assessment should it ever be called upon to determine the lawfulness of maintaining somatic support for a brain-dead pregnant woman. This should include reference to the manner in which a woman is being medically sustained and, in particular, any past views she may have expressed about what she would want to happen, as well as giving some consideration to any values and beliefs that she may have held while alive that may have affected her thinking. Within this wider balancing exercise, due consideration ought also to be given to the foetus, with particular emphasis being placed on what the medical evidence is indicative of not only in respect of its chances of survival, but also in regard to any potential pain and suffering that the child may be exposed to once born, and how this may subsequently impact upon its existence in the future. Last but not least, the views and wishes of the unborn child's father and relatives, who will usually have a huge part to play in looking after the child once it has been born and who, therefore, have a vested interest in the final outcome, should be accommodated within a judge's decisionmaking process. This approach would serve to ensure that the perspectives of all the important parties within this tragic scenario are given adequate respect and due consideration in the eyes of the English law. 